\title{
Genocide of Rohingya Muslims and Role of Contemporary World Actors
}

\author{
Safdar Ali \\ Ph.DScholar \\ Institute of International Relations \\ Shah Abdul Latif University, Khairpur \\ Dr. Amir Ahmad Khuhro \\ Professor \\ Institute of International Relations \\ Shah AbdulLatif University, Khairpur \\ Dr. Liaquat Ali Chandio \\ AssistantProfessor \\ Institute of International Relations \\ Shah Abdul Latif University, Khairpur \\ Aijaz Ahmed Shaikh \\ Ph.DScholar \\ Department of International Relations \\ Universityof Karachi, Karachi
}

\begin{abstract}
:
Myanmar is the region of Buddhist religious community where lived other races as minorities like Rohingya Muslims. From many decades the Muslims have been victims of widespread violation policies of the Myanmar government. It is adopted gradual, multidimensional discriminatory and oppressive policies against the Rohingya people. The proposed research is an attempt to explore the reasons behind genocide activities took against the Rohingya as a Muslim minority in Myanmar (former Burma). The Muslim minority issue in Myanmar is attached to the past when they came and settled in southern areas of the former Burma (Myanmar). The Rohingya minority crises are also creating the political and regional tensions. So, the local and international powers are diverting their attention to handle the issues of Rohingya Muslims as well. Through the deductive and analytical approach very best tried to analyze the social and ethnic factors into the scenario of Rohingya Muslims genocide confronts within the structure of non-traditional security crisis. The inhuman activities against Rohingya Muslims can stop and bring about a durable solution by the concrete efforts of the local and international communities.
\end{abstract}

Key Words: Rohingya, Genocide, Myanmar, World Actors, UNO 


\section{Introduction:}

The genocide is an inhuman activity and denial of the right of human existence because of any specific reason or conflict. The genocide is the term used for the killing and arson of people and causing serious mental and physical harm by any brutal person or group. It is deliberately inflicting on the life conditions of peoples. The crime of genocide consisted of three basic objectives as the presence of a protected group, the commission of one and more acts to secure the people and the requisite intent as well. ${ }^{1}$

According to official estimates there are about three million Muslims in Burma, who constitute about ten per cent of the Burmese population and from the largest religious minority group. The first Constitution of independent Burma had recognized Islam and Christianity as religions besides according a special status to Buddhism. Muslims are spread all over the country. There are groups of Muslims in towns and villages, particularly in the Shwebo, Kyanko, Kayanksa, Pyinmana, Moulmein and Moulemingyun areas. Burmese Muslims can be roughly divided into two groups:

(1) Those of South Asian origin, particularly in the Arakan region, who retain some links with South Asian countries.

(2) Those who are Burman or have become Burmanized, whose language is Burmese. There is also a small number of Chinese Muslims or their descend ants.

Burmese Muslims have acquired some proficiency in Urdu, due to their association with Urdu-speaking people of Rangoon, though the state has never encouraged foreign languages such as Urdu. ${ }^{2}$ The largest concentration of Muslims is in the Arakan region (around' two million), which borders tñe Chittagong Hill Tracts of Bangladesh. The old name of Arakan is Rohang, Roshang or Oranshin, which is a term attributed to the coastal region along the Bay of Bengal. The 150 or 170 Mile long Naaf boundary forms the frontier between Bangladesh and Burma. The Arakan is entirely cut off from the rest of Burma and lies between the Arakan Yoma and the Bay of Bengal. Etymologically the origin of the term Arakan is Arabic, and the region itself is 14,914 Square Miles in area. In the $8^{\text {th }}$ and $9^{\text {th }}$ centuries of the Christian Era the Arab merchants flourished in the Arakan and the coast of Bengal; they established extensive 
relations with the inhabitants of the sea-ports of these regions. The present Muslim population is mostly the direct progeny of the early settlers, Arabs and others from Bengal, Orissa, Madras, and of the converts. The converted Muslim King Sulaiman Shah (Saw Mwan) established the Marauka dynasty in 1430 AC in the region with the support of the Illeyas Shahi Sultan, Nasiruddin Shah of Gaur, (Gaur was then the capital of Muslim Bengal). Persian was first introduced by Sulaiman Shah as the Court language (as in the Subcontinent) and it remained the Court language till 1836 even after the British conquest of Arakan in 1824-1826. Arabic was adopted as the religious language of the Muslims. ${ }^{3}$

In Rakhine State on the western coast of Myanmar, the Rohingya are a Muslim minority group. According to numerical evidences, one million Rohingya live in the northern township of Rakhine The government passed an act civil society, called the Citizenship Act of 1982, through which Rohingya has negated the equality between citizens of its people. The government of Myanmar, its military, security forces and the Buddhist community played a

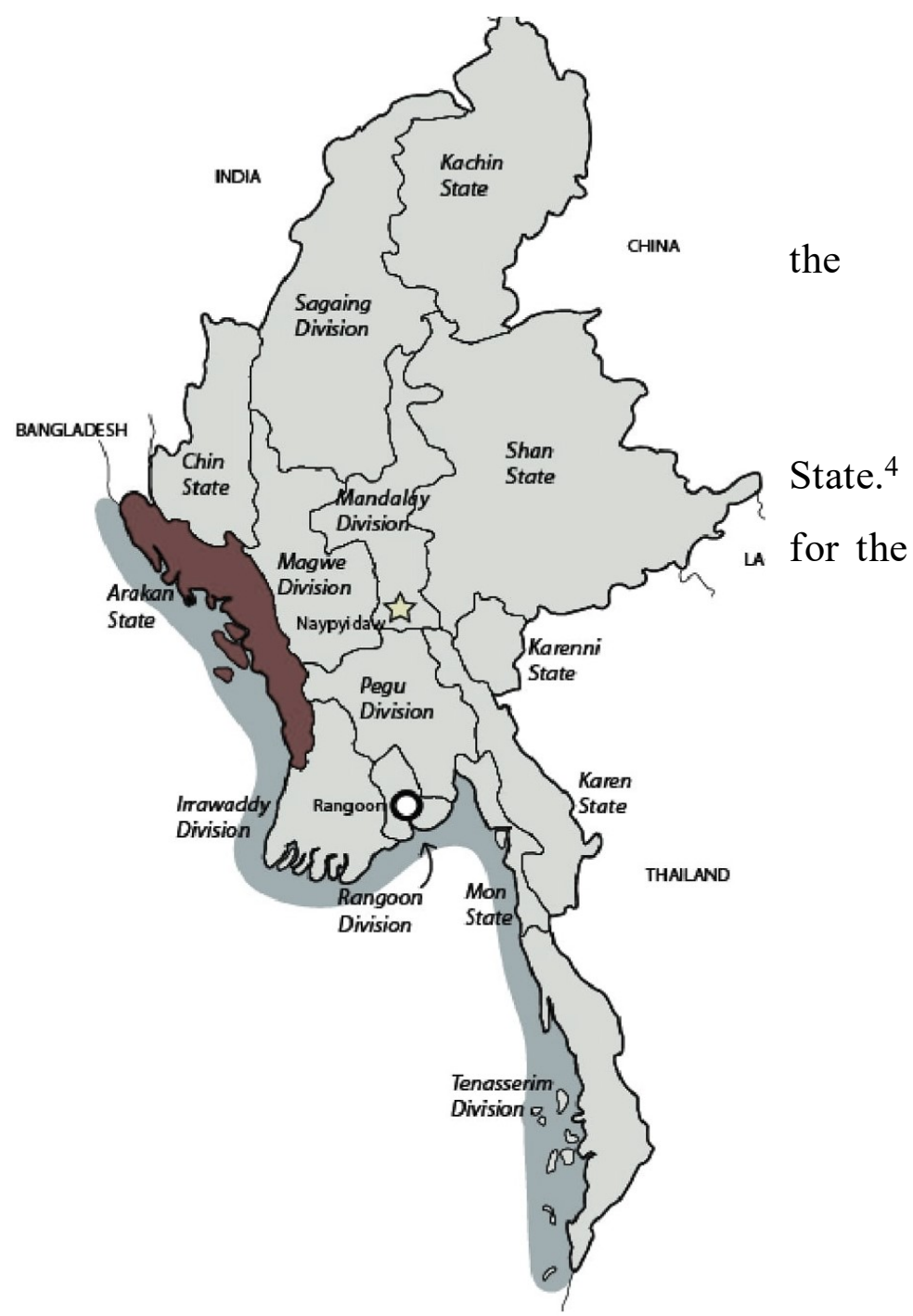
key role in human rights $200 \mathrm{~km}$ violation of Rohingya Muslims in Rakhine. The number of men and women in Rakhine are tortured by the physical and psychological violence. Moreover, they are 
deprived of the basic human rights of liberty and other needs as of diet, education, political rights and economic opportunities. These all are the factors, which intended them to go away from the boundaries of Myanmar and settled in other areas of the world where can avail the basic facilities of life and liberty.

\section{Rohingya as an Ethnic Group:}

According to the historical evidences, the Muslims in Myanmar were settled in the $12^{\text {th }}$ century and during the British period, when it was the colonial province, the number of people as labours migrated from different areas of Bangladesh and India as well. After the independence of Myanmar (former Burma), the migrated people were not accepted by the indigenous community and Rohingya considered as the illegal citizens.

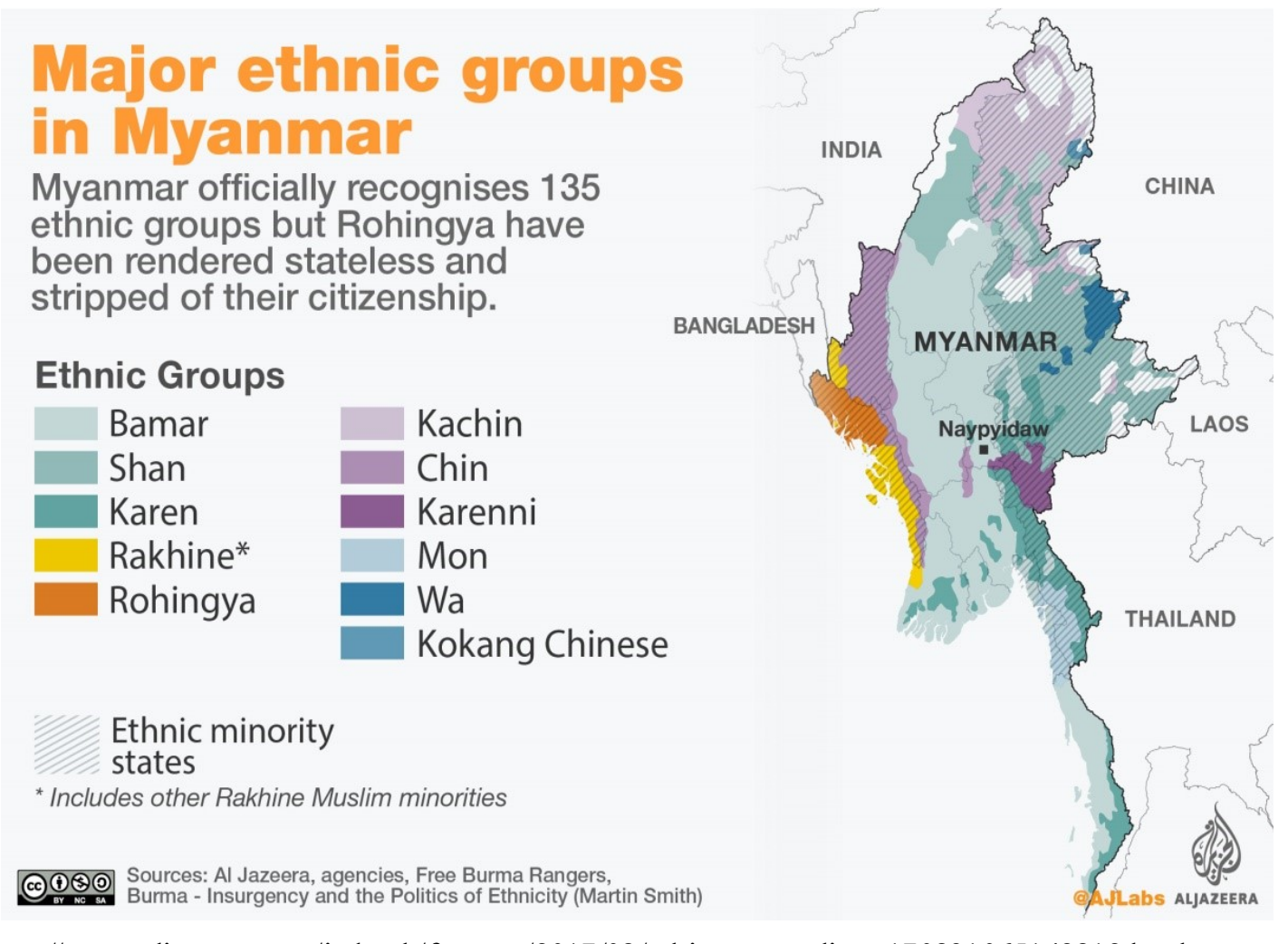

http://www.aljazeera.com/indepth/features/2017/08/rohingya-muslims-170831065142812.html

The Rohingya ethnic group is considered as the most persecuted minority in Myanmar. The word Rohingya is the name historically given to the Arakanese Muslims. It is a village of Muslims in Akayab (Sittwe) city by the name of Rohingya para. It is also believed that the old name of Rakhine state was 'Rohang' from which 
the term Rohingya was derived. ${ }^{5}$ It is claimed that they are the people who speak Ruaingga language that makes them distinct to other people of Rakhine state and the Myanmar. The Rakhine is one of the poorest region of the country where the people deprived of the basic needs and opportunities of life. They are not considered as the part of other about one hundred and thirty five official ethnic groups and the citizens of Myanmar since 1982 AD. Furthermore, they are bound to get permission from the

government to live in the western coastal areas of Rakhine State. According to the report of the International Human Rights Clinic at Yale Law School presented in 2015, under the general provision, the Rohingya was not included in the early law of citizen, but some families, who lived for many generations in Myanmar, allowed giving application for their identity cards. However, after the military coup of 1962, the situation changed and foreign ID cards were issued to the Rohingya, which limited professional, social and educational opportunities for them. The Rohingyas are considered as the Bengali migrated people and the Buddhists of Myanmar not ready to accept them as their own fellows. As a result, the Rohingyas are treated brutally by the Buddhists, because of the violence and persecution; thousands of Rohingya have migrated towards other areas (Bangladesh, India, Malaysia, Thailand and Southeast Asian countries) through land and boat.

\section{Onslaughts Against Rohingya:}

The inhuman attitude against the people of Rakhine can be observed by elaborating different brutal activities of the indigenous ethnic groups of Myanmar. Consistently, the Rohingya people are facing cruel activities of Buddhist religious and ethnic groups since 1970 AD. In 2013, the operation against Rohingya ethnic cleansing was also started by the Buddhists of Myanmar. Through the crackdowns and terrorist activities, the Rohingya people forcefully expelled from their houses. In 2016, the government military troops entered in the villages of Rakhine state after the killing of nine border policemen because the Rohingya groups blamed the killers and fighters. During the military crackdown on village areas of Rohingya, the troops adopted inhuman attitude and denied all human rights and social laws brutally. The ethnic cleansing, killing, women rape and other inhuman acts of the military can be observed. 
During the running year, the conflicts in northern Rakhine state of Myanmar were highly worsened and a great threat for the stability of the state. The government of Myanmar took harsh counterinsurgency operations against the Muslim community of Rakhine because they confronted with the Arakan Rohingya Salvation Army (ARSA) and killed many soldiers. As a result, the Myanmar army started operation against the Rohingya Muslims and adopted inhuman acts, so more than six Lac Muslims migrated towards other neighbouring border areas. According to the evidences, the soldiers committed so cruel acts in which including killings of civilians, infanticide, summary execution, the burning of villages and gang rape. So, more than four Lac people (previously lived in Myanmar) migrated towards very near border areas of Bangladesh and are struggling to live under the Bangladeshi society. In the refugees are including a number of undernourished children the women because they are considered the illegal Bangladeshi migrants by the Buddhist community of Burma. However, the Bangladesh is not ready to recognize the Rohingya Muslins as the former citizens of it.

At the international political front, Myanmar may consider as the peaceful and humanitarian country but after the crises of Rohingya Muslims, its view changed in the eyes of foreign state actors. It can say that, behind the inhuman acts against Rohingya Muslims is working other political, strategic and cultural motives of the Myanmar (former Burma) government. The state councilor Aung San Suu Kyi played a key role to develop a peace building nation of Buddhist community. She got the Nobel Peace prize in 1991 because of her humanitarian, peace building and social welfare activities. After her father's death, she led to the party called National League for Democracy (NLD) and considered as the champion of human rights and also spent fifteen years under house arrest by the former militant government of Myanmar. In 2015, she succeeded in the first contested elections and took office in April 2016. However, some uneven activities of the party members and its support of the conservative groups made it suspected. The NLD favoured the Buddhist dogmatism, shared power with the military men who are working under the supervision of General Min Aung Hlaing (commander-in-chief). The rigid Buddhists are the real sponsored of 
the Rakhine issues because they directly protected by the military and the political party of Aung San Suu Kyi.

The Rohingya Muslims and Buddhist conflicts and violated events are not new but keeping an old history of confrontation. In different decades, many Muslims migrated towards different areas of the world because of inhuman behavior and violence of the Burmese. Currently, the situation becomes more worst because the Buddhist claimed that Muslims of Rakhine, attached with the ARSA militant group, attacked on the soldiers and killed some soldiers. As a result, a harsh reaction can see from the military and civilians of the Myanmar and thousands of Rohingyas brutally killed, burned and women raped by them. However, they totally refused to accept that they adopted inhuman and so violated acts against the Muslims of Rakhine. In the current year, Zeid Raad Al-Hussein (High Commissioner for Human Rights of UN) visited and said that the Buddhist rigid people tried their best to clean sweep the Muslims and emphasized on the investigations to know the real truth about the Rohingya Muslims in Myanmar. ${ }^{6}$

\section{The Humanitarian Crisis \& World International Actors:}

The international response to the increasing humanitarian emergency in the Myanmar and Bangladesh borderlands faces multiple challenges. Access to the most severely affected areas of northern Rakhine State is inadequate and incomplete, with aid organizations struggling to find leverage at a time when Myanmar's government is under immense pressure from its own people to maintain an uncompromising position about the exclusion of the Rohingya. While there is general sympathy for the displaced Muslim population, humanitarian efforts on Myanmar's side of the border usually allocate resources disproportionately to the Buddhist Rakhine due to ethnic, religious and political favouritism. On the border of Bangladesh, the humanitarian emergency has prompted the Bangladeshi government to rapidly construct basic accommodation and sanitation facilities, and to institute programs for mass immunization. While the government has offered some logistical, administrative and financial support, it is also cautious about expending its limited resources on the 
unpopular Rohingya.

Attention has already turned to a possible long-term solution to the increasingly grave situation. While there is talk in both Myanmar and Bangladesh of repatriating some Rohingya to their homes in Myanmar, the management of that process would be emotionally taxing and highly politicized. Among the population of Myanmar and most acutely within Rakhine Buddhist circles, there is broad refusal to recognize the right of the Rohingya to live in northern Rakhine State. From this widely-held perspective, the recent exodus is seen as a welcome development fitting a prevailing narrative that 'illegal migrants' are destined to return to Bangladesh. For this reason, it appears unlikely that Myanmar's government will allow the prompt identification, processing and repatriation of large numbers of people who should, under the country's law, be afforded residency.

The required scale of the response has tested international agencies and nongovernmental organizations. Fears are increasing that disease, hunger and fighting over limited resources could intensify hardship. According to the UN, member states had pledged US\$116 m of the US\$430 m sought by the UN over the next six months for humanitarian aid in Myanmar. Nevertheless, as around one million people have scant access to clean water, sanitary facilities or medical care, Joanne Liu, international president of Médecins Sans Frontières (MSF), described the situation as a time bomb ticking toward a full-blown health crisis. As one of Asia's poorest countries, Bangladesh has problems of its own, and the southeastern portion of the country, an area already densely populated by earlier waves of displaced Rohingya, is serviced by only a few narrow roads. An outbreak of disease or violence would further exacerbate this tense situation and would make the delivery of essential aid and services even more difficult. Bangladesh is also disinclined to accept the permanent settlement of the Rohingya.

\section{Blemished Democracy in Myanmar:}

Myanmar is now ruled by an uneasy coalition of political interests, with the most 
prominent figures drawn from the ranks of democrats like Aung San Suu Kyi, and militarists like Senior General Min Aung Hlaing. In Naypyidaw, the decade-old capital in central Myanmar, these groups, previously defined by their mutual hostility, have formed functional working relationships. Under the country's 2008 constitution, the armed forces are a primary and permanent pillar of national strength. Various safeguards against unchecked political reform are in place, and the armed forces' assent remains integral to all major governmental decisions. Thus, while the NLD triumphed in the 2015 general election, Aung San Suu Kyi is compelled to work closely with the military leadership, including the commander-in-chief and the three military officers constitutionally mandated to serve in the cabinet in the key nationalsecurity positions of defense minister, home-affairs minister and border-affairs minister.

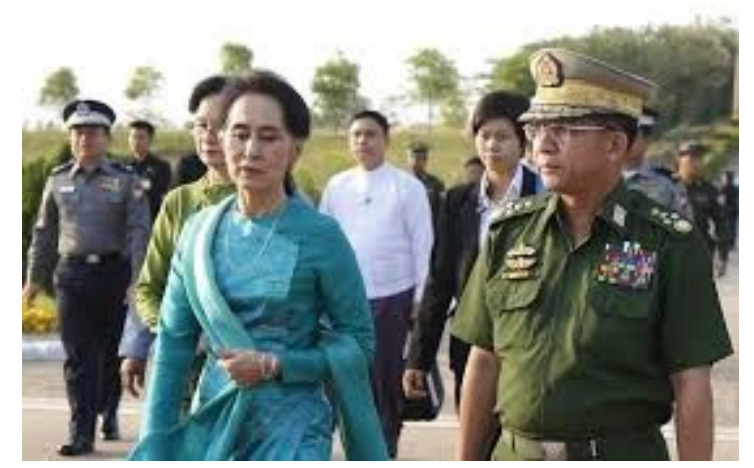

At the same time, the National League for Democracy (NLD) won the 2015 general election with a straight forward demand for 'change'. Its policy vision remained undeveloped, but millions of people were simply relieved that they could vote for Aung San Suu Kyi's democratic movement, which was already famous for its principled stand against military dictatorship. Before the election, her primary concern was to become president. After her victory, she sought to alter Myanmar's constitutional framework in favour of civilian power. When it became clear that no compromise with the armed forces was possible - they barred her from assuming the presidency - she side stepped their obstacles and created the new position of State Councilor, which she described as 'above the president'. Surrounded by a relatively inexperienced leadership team, in which a few political veterans also served the former military regime, Aung San Suu Kyi struggled to maintain positive political momentum and executive control in her first months in power. The Rohingya situation is her first major international crisis.

Most people in Myanmar ignore Bangladesh, which in turn devotes most of its foreign 
policy attention to India and, increasingly, China. Yet in Bangladesh, displaced Rohingya have become a focal point of the messy, mass-mobilization politics that incorporates a tug-of-war between duelling political dynasties - the secular Awami

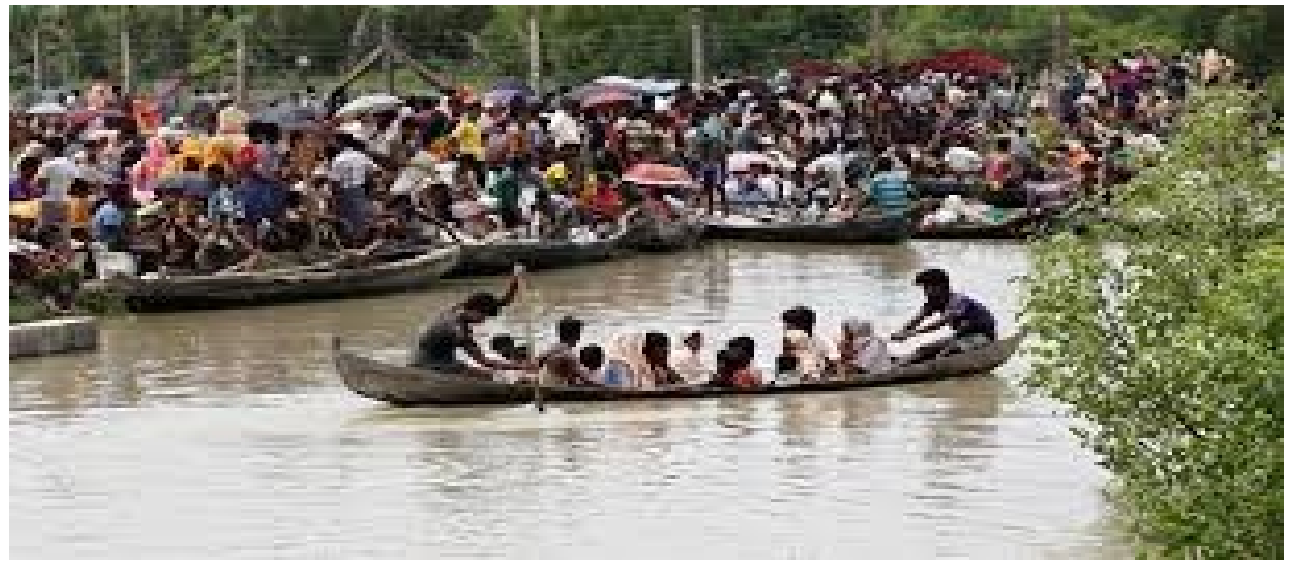

League, now in power and the

moderately Islamic Bangladesh National Party (BNP) and continually threatens a putatively secular, liberal cast of government. While most Bangladeshis support Prime Minister Sheikh Hasina's calibrated assistance to the Rohingya, the BNP has criticized her for refraining from labelling Myanmar's crackdown a 'genocide', called for sanctions on Myanmar and impugned the government for failing to engage India and China more intensely to help manage the crisis but India, though it has traditionally had an agreeable relationship the Awami League, values Myanmar's counter-terrorism cooperation, shares its government's general distrust of Muslims and firmly backs its stance on the Rohingya crisis. In turn, Islamists have gained influence in Bangladesh's politics. Hefazat-e-Islam, the country's most powerful Islamist group, runs some 25,000 madrassas, advocates the liberation of Rakhine State and has threatened to wage jihad in Myanmar if its perceived abuses of Rohingya Muslims do not end. Accordingly, Hasina must walk a fine line between responding to the BNP, Hefazat-eIslam's advocacy for the Rohingya, and catering to India's wariness. Should this prove too difficult, and produce instability, she could default to outright authoritarianism.

\section{Image of Myanmar in International Arena:}

The displacement of so many Rohingya will have long term geopolitical ramifications and given increasingly fragile international reputation of Myanmar. Now, it is receiving more media and political attention than at any time since the abortive 2007 
Saffron Revolution, and the majority of coverage has taken a dramatically negative turn. In some Muslim-majority countries, such as Indonesia and Malaysia, bad press has catalysed protests against the Myanmar government and sparked calls for a tough response. Key western democratic governments, which have customarily encouraged further political reform in Myanmar have been outspoken in their criticism and some have taken action. The United States (US) and the United Kingdom (UK) have suspended military cooperation with Myanmar. Earlier this week, the US Department of State suspended travel waivers permitting former and current senior military officials from Myanmar to enter the United States, foreclosed US aid to military units involved in the repression of the Rohingya and was considering broader economic sanctions. The European Union (EU) has vowed to consider diplomatic and economic measures against Myanmar if its response to the crisis does not improve. Criticism is likely to intensify as more evidence of human-rights abuses accumulates and is assessed.

China is Myanmar's most important international partner, accounting for over $22 \%$ of its official trade. With over two million Chinese citizens or former citizens living in Myanmar, links exist at all levels and across all aspects of society: economics, politics and culture. China prudently welcomed the country's greater openness and embraced the opportunities for bold investments and collaboration. Beijing, not unpredictably, is supporting Myanmar's position in the Rohingya crisis, having joined Russia to shield Myanmar from condemnation by the UN Security Council. The gradual liberalization of Myanmar's dictatorial system expanded its scope for other bilateral relationships. Regional players such as Singapore and Thailand have tended to take pragmatic approaches to difficult regional political issues, including the Rohingya crisis. India, as noted, has sided with Myanmar on that score. None of these regional actors is likely to dramatically shift its overall policy. But Indonesia and Malaysia, in which national leaders face elections over the next two years, may extend more energetic support to the Rohingya. Those leaders have more to lose if their governments look weak in the face of what their people condemn as an anti-Rohingya progrom. Accordingly, the crisis stands to produce rifts between Muslim-majority and other nations within the 
Association of South East Asian Nations (ASEAN).

The most unpredictable aspect of the geopolitical situation relates to the broader Muslim world. The jihadist groups and movements beyond Southeast Asia have declared their interest in the problems of the Rohingya, and some may be motivated to shift operations against the Buddhist community of Myanmar. Moreover, the followers of the Islamic State as ISIS and Al-Qaeda have reportedly been trying to recruit Rohingya through media and other sources.

\section{Rohingya Dilemma and International law Against Myanmar:}

The Rohingya people are victims of the most awful human rights violations for quite some time. Killings, arson, rape, torture and worst kind of degrading treatment to women and children have gone beyond imagination. The inaction of the powerful states and international organizations has shaken the conscience of men and women around the globe. The powerful states and even the responsible persons of our government are yet to dub it 'Genocide' in loud and clear terms. Although, it is denied by the rulers of Myanmar, there is hardly any doubt from objective evidence that the military in Myanmar are systematically and forcibly removing ethnic Rohingyas from their homeland. These actions have been widely condemned by many international organizations and renowned personalities of the world.

Most observers ponder on the implementation of international humanitarian law to stop the human rights violation. However, there are problems as regards the applicability of international law. International law in this regard comprises some other individual rules and regulations such as criminal law, human rights law and social harmony rules.

The term of international law was constructed in the last decade of the twentieth century during the Yugoslavia civil war. There have been made different UN conventions against Torture (UNCAT) prohibits acts of torture, anti-human and insulting behaviour. To protect the human beings and to secure their properties were made general rules as the International Covenant on Civil and Political Rights 
(ICCPR) and International Covenant on Economic, Social and Cultural Rights (ICESCR). These treaties were made to secure the ethnic groups and their rights of life, food, social status and ethnicity. However, it may possible that the government of Myanmar did not accept the ICCPR, ICESCR, UNCAT, the Race Convention.

Furthermore, the ethnic base conflicts and genocide activities were bounded or prohibited in 1948 through the 'Genocide Convention'. According to this convention, genocide considered a crime which causes serious physical and mental harm to a specific group or the large people of any population on the basis of ethnicity. Myanmar was the member and accepted the conditions of genocide convention but now there is no appliance of it in the Rakhine issue against Muslims. There was made an International Criminal Court (ICC) against genocide issues of any region and community in the world.

In case of Myanmar, they are not a party to the ICC. As such, the likelihood of the Court exercising its jurisdiction with regard to the Rohingyas does not hold out much prospect. However, if the Security Council of the UN decides to refer the case to ICC, things may take a different turn. This has not happened so far. One can only look up to such a bold move. Undoubtedly, there is a complex web of international law where responsibilities and obligations are at crossroads. All are parts of international law but the application and the role of actors, at the end of the day, will be the key. Politics and economic interests, not surprisingly, determine what would happen. Nevertheless, international law in its different manifestations may pave the way, if it is rightly called upon to do the needful. ${ }^{7}$

For some time, the priority will be ensuring the safety and sustenance of the newly displaced Rohingya. Sanitation in the overcrowded and hastily constructed camps of southeastern Bangladesh is a chief concern, with aid groups anxious about possible outbreaks of disease. Vaccination programs may prove inadequate under what are, by any standard, grueling conditions. Myanmar's government has brutally redefined the political and social landscape of northern Rakhine State, perhaps on a permanent basis. While some Rohingya will likely be part of the suggested repatriation process, 
many others are bound to face long-term exile on the Bangladeshi side of the border. Those who are able to work will occupy the lowest rungs of the employment ladder and will struggle to fit into a poor country which is already straining to feed a population of 165 million. Bangladeshi government spokespeople have warned of the prospect of Rohingya radicalism. If violence re-ignites in Bangladesh, the government is likely to become even less sympathetic to the Rohingyas needs.

Given the depth of Muslim feeling about the world's perceived lack of attention to the Rohingya crisis, jihadist groups operating cross Southeast Asia, Central Asia and the Middle East may see Myanmar as a new target for political, paramilitary and terrorist campaigns. These groups can manipulate the history of mutual affection between Aung San Suu Kyi and western democracies to imply that the latter endorse antiMuslim violence in Myanmar.

Aung San Suu Kyi's reputation is unlikely to recover fully from the battering it has taken over the Rohingya crisis. Myanmar will probably limp towards the planned 2020 general election without the recent high level of international endorsement. Its decision-makers may revert to their previous practice of relying on Chinese business and government links to support national development. Other alliances of opportunity or convenience may emerge for Myanmar from the current crisis, especially with countries that feel similarly besieged by Muslims, such as India, Israel and Sri Lanka. Even in the face of mounting evidence of egregious human-rights abuses, Myanmar will probably continue to present itself as a valiant defender of Buddhist civilization against external threats - radical Muslim groups in particular. The conflation of ordinary Rohingya claims for tolerance and respect with the demands of extremist Islamist ideologues is likely to remain the standard response from the Myanmar government. The crisis, then, has abruptly blunted Myanmar's international rehabilitation. 


\section{Rohingya Refugees and International Assistance:}

Thousands of Rohingya refugees migrated towards Bangladesh and other areas of the world. The report of UNHCR explained that in early days of running year more than seven lac Rohingya people were entered in the village of Anjuman Para situated, Bangladesh. Later on, near about 6.5 million Rohingya refugees reached in the neighbour country and many still stranded in Myanmar. For the financial assistance of these people, different organizations including UNO announced to give sufficient amount to them. The amount will spend on the settlement, food, health and financial assistance of the Rohingyas.

In a conference meeting of United Nations was decided to give near about four hundred millions dollars for the relief of Rohingya refugees and the host communities in Bangladesh. Mark Lowcock, the Under-Secretary-General for Humanitarian Affairs and UN Emergency Relief Coordinator said that currently there is a core need of unity and solidarity between the humanitarian donors who are able to support Rohingya, properly. The United Nations agencies have increased their relief activities of health, food and security for the people especially for refugees of Myanmar. However, the crises scale is more rather than the help and still required basic needs of life as shelter houses, clean water, food, medicines, cloths and security for the refugees.

For the security of life and liberty, about eight lac Rohingya people migrated towards Bangladesh but are keeping hope that may in future their identity recognized by the Myanmar majority Buddhist community and they go back in their homes. Many refugees of Rohingya Muslims pay a heartily tribute to the Bangladeshi people and government because of their kind support and favour to them. ${ }^{8}$ Furthermore, other states and communities of the world are coming ahead to give financial support and access to other needs of life to the Rohingyas. By the several donors has been given more than fifty million dollars as assistance to them. ${ }^{9}$ 


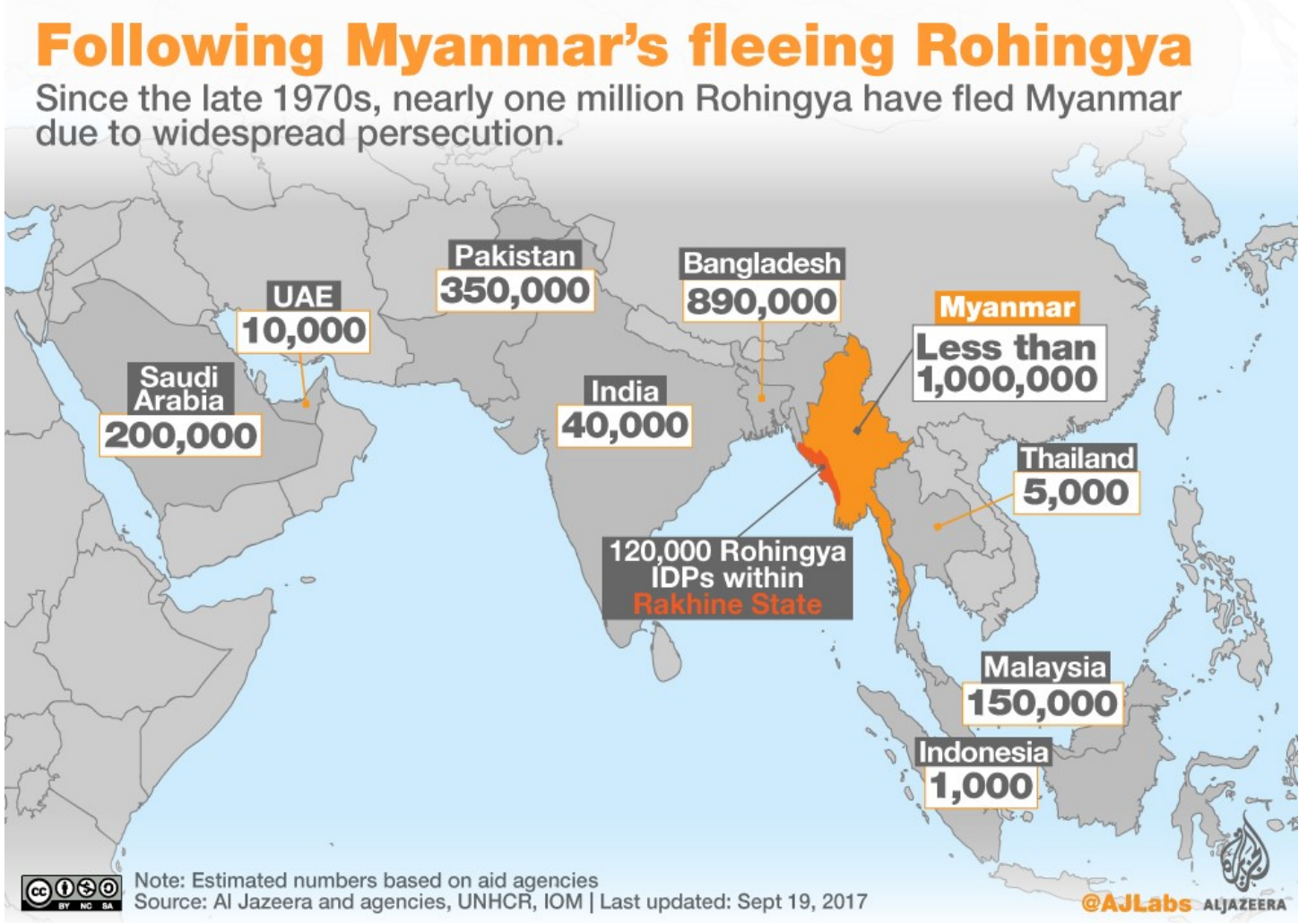

\section{The United Nations \& Rohingya Muslims:}

When the Rohingyas migrated towards other areas of the world including Bangladesh, have left behind everything they had once known in the face of the Myanmar military's brutalities against their own people. It can assume that it has all happened because of the collective failure of the United Nations members to prevent and stop the carnage. The Rohingya crisis has steadily deepened resulting in one of the worst human catastrophes in recent history. More than half a million people have already crossed the border into Bangladesh in less than two months. This is an unprecedented tragedy in human history. Yet, it was in the making for several years, long before the recent burning and killing started, the warning sign were already there, building upon decades of persecution of the minority by the Buddhist majority in Rakhine state. The state media continuously attacked the identity of the Rohingya Muslims and falsely claimed that Rohingyas were outsiders and illegal Bengali migrants to Rakhine despite historical evidence of their presence in the Arakan region since pre-British period.

According to some observers, the hatred and violence unleashed against Rohingya Muslims is an eerie reminder of Rwanda before the genocide there. When some 
Rohingyas took up arms to fight back against their decade's long persecution, the Myanmar military mounted a disproportionate response leading to the burning and looking of Rohingyas forcing them out of their own country.

The men, women and children of Rakhine state who survived under most crucial situation of violence and crossed the border to Bangladesh shared consistent accounts of Myanmar soldiers surrounding their village, burning homes to the ground stabbing and shooting innocent villagers and committing mass rapes. According to refugees international, the attacks and displacements that began in late August, 2017 are of an entirely new scale and level of inhumanity. In addition to the more than half a million who have fled to Bangladesh an estimated 200,000 people have been internally displaced in Myanmar's strife-hit Rakhine. It is shameful that this tragedy happened under the leadership of Myanmar's de facto leader Aung San Suu Kyim now branded as one of the great ethnic cleansers.

The responses to date by the United Nations as a world body can at best be described as dismal. The condemnation by the secretary general has not helped in any form or shape. Instead, an early response from the UN Security Council could have changed the tragic outcome in Myanmar. The Security Council particularly two of the veto wielding permanent members, China and Russia should get the lion's share of the blame for the lack of any decisive action. The failure of the Security Council has simply emboldened the Myanmar regime to continue its abuses against the Rohingya civilians.

This is amply demonstrated according to refugees international by the refusal of the Myanmar regime to allow access to the UN fact finding mission to investigate human right abuses and unfettered access to humanitarian organizations for relief and rehabilitation in Rakhine. The Asian countries have also equally failed the Rohingya refuges; the only response to the crises has been statement expressing concern over the situation. It has failed to take a stand against one of its member states caring out a violent campaign of ethnic cleansing and for crimes against humanity.

Amnesty international accused Asian of failing Rohingyas and asked the member countries to uphold the commitments to human rights and include in the Asian charter. Finally, the US state department recently expresses concerns that the Myanmar 
crackdown on the Rohingyas may destabilize the region and could draw international terrorist. However, there was no word on any punitive actions and weather the Trump administration would impose targeted sanctions against Myanmar military. The situation on the ground in Bangladesh demands urgent attention and support for Rohingya refugees.

\section{Measures to Secure the Rohingyas:}

To secure the Rohingya Muslims of Myanmar, the UNO and other International actors decided to take consolidate measures in which including:

- To stop violence against Rohingya Muslims, it is essential to pressurize the government of Myanmar and its rigid groups by the indulgence of strong countries like America and China.

- The Investigation groups and delegations of the world should send in Myanmar to investigate the facts about Rohingya Muslims.

- The Rohingya Muslims should support by the UNO and it tried to provide their rights as citizens of Myanmar

- The government and people of Bangladesh should admired and financially supported by the international actors/powers

- There is a core need of the serious efforts and collaboration of regional power such as China, India and other SAARC countries with the UNO to secure the Rohingya Muslims in Myanmar.

- The international powers and regional communities should deal with the violation of human rights, destructions and torcher, perpetrated by the Myanmar rigid groups and the military men.

- In fact, the Rohingya human rights violence is a great tragedy and a wakeup call to the international community to step up their efforts and solves the problem properly. ${ }^{10}$

\section{Conclusion:}

The great Burmese leader, $\mathrm{U} \mathrm{Nu}$, once said : "Mistrust begets mistrust ...trust also begets trust, and confidence begets confidence." The relations between the Burmese and other indigenous races and religions, particularly the Muslims, will only become 
completely satisfactory when this excellent maxim is fully put into practice. "Considered geographically, the purpose of the political organization of a state is to establish coherent unity and certain degree of homogeneity over areas which without the state organization are more or less separate and heterogeneous. In other words, the state seeks to create a region of high degree of functional unity and in certain respects of high degree of uniformity. Only human political agencies can create such regions; they are not given in nature." Few states can claim homogeneous populations in their territories. Nation-states can be built only by giving a sense of participation to their minorities, which in return gives a sense of 'belonging' to the state. It is hoped that the Burmese leadership will take note of the fact that "nationalism is the individual's identification of himself to the 'wee-group' to which he gives supreme loyalty."

About the issues and miserable condition of Rohingya Muslims, Sheikh Hasina Wajed Bangladesh's Prime Minister gives her five points plan in her speech on $23^{\text {rd }}$ Sptember, 2017 at the UNOs plateform. Further, she called for the proper and permanent solution of the Rohingya refugees to end the ethnic cleansing activities of Myanmar.

In the floating 5 points of Bangladeshi Prime Minister are included that;

"Firstly-Myanmar must stop human rights violence and practices of ethnic cleansing in Rakhine state unconditionally, immediately and forever. Secondly-The United Nations Secretary General should immediately send fact finding mission to Myanmar. Thirdly-All civilians, irrespective of religion and ethnicity must ne protected in Myanmar. Fourthly- For this, safe zones can be created inside Myanmar under UN supervision so that sustainable return of all forcibly displaced Rohingyas in Bangladesh to their homes in Myanmar. Fifthly-Recommendations of Kofi Annan Commission report must be implemented immediately, unconditionally and entirely."11 


\section{References}

Convention on the Prevention and Punishment of the Crime of Genocide, adopted Dec. 9, 1948, 78 U.N.T.S. 277 (1951) [Genocide Convention].

2 Dawn, Karachi, 1 December 1978

3 Mujtaba Rizvi, (1978). "The Problems of the Burmese Muslims", Pakistan Horizon, (Vol. 31, No. 40), Fourth Quarter, Pakistan Institute of International Affairs, pp. 82-93, http://www.jstor.org/stable/41394695

$4 \quad$ Estimates vary and the most recent government census, conducted in 2014, excluded Rohingya from the count. Rakhine Inquiry Commission, The Republic of the Union of Myanmar, Final Report of Inquiry Commission on Sectarian Violence in Rakhine State, pp. 3, 78 (July 8, 2013)

5 Charney, M. W., (2005), Buddhism in Arkan: Theories and Historiography of the Religious basis of Ethnonyms, History Conference in Bangkok,

6 Azeem Ibrahim, The Rohingyas: Inside Myanmar's Hidden Genocide, oxford, 2016, p.10

7 https://thefinancialexpress.com.bd/views/views/rohingya-crisis-invoking-internationallaw-against-myanmar-1509028258

$8 \quad$ Filippo Grandi's address, (UN High Commissioner for Refugees), 2017

9 http://www.un.org/apps/news/story.asp?NewsID=57940\#.WgyJO4hx3IU

10 Muhammad Zaman, "Has UN failed the Rohingyas", The Dawn, $11^{\text {th }}$ October 2017, Karachi

11 https://currentaffairs.gktoday.in/bangladesh-pm-sheikh-hasina-floats-five-point-peaceplan-rohingya-crisis-09201748349.html, accessd on 29-11-2017 